\title{
A syntenin-like protein with postsynaptic density protein (PDZ) domains produced by black tiger shrimp Penaeus monodon in response to white spot syndrome virus infection
}

\author{
Phuwadol Bangrak ${ }^{1}$, Potchanapond Graidist ${ }^{2}$, Wilaiwan Chotigeat $^{1}$, \\ Kidchakan Supamattaya ${ }^{3}$, Amornrat Phongdara ${ }^{1, *}$
}

\author{
${ }^{1}$ Department of Biochemistry, Faculty of Science, Prince of Songkla University, Hat-Yai, Songkhla 90110, Thailand \\ ${ }^{2}$ Department of Biotechnology, Faculty of Agro-Industry, Prince of Songkla University, Hat-Yai, Songkhla 90110, Thailand \\ ${ }^{3}$ Department of Aquatic Science, Faculty of Natural Resources, Prince of Songkla University, Hat-Yai, Songkhla 90110, Thailand
}

\begin{abstract}
We report the isolation and characterization of products from a subtractive cDNA library from the haemolymph of Penaeus monodon experimentally infected with white spot syndrome virus (WSSV). One cDNA derived from up-regulated mRNA was identified. A homology search indicated similarity to the putative protein syntenin (TE8). The nearly complete nucleotide sequence of TE8 was obtained by rapid amplification of CDNA (RACE). Its putative protein product contained a tandem repeat of PDZ domains (postsynaptic density protein or PSD-95, DlgA and ZO-1). We propose that TE8 may function as an adapter that couples PDZ-binding protein(s) in a signaling pathway involved in the shrimp response to WSSV.
\end{abstract}

KEY WORDS: White spot syndrome virus $\cdot$ Penaeus monodon $\cdot$ Signal transduction $\cdot$ Syntenin $\cdot$ Postsynaptic density protein $\cdot \mathrm{PDZ}$

\section{INTRODUCTION}

In the last decade, the Thai and southeast Asian shrimp industry has been hampered by viral disease epidemics, particularly from white spot syndrome virus (WSSV) and yellow-head virus (YHV) (Flegel 1997). Despite the importance of these viral diseases, there is little knowledge of the nature of the interaction between shrimp, or crustaceans in general, and viral pathogens (Flegel 2001). To address this lack of knowledge, there is increasing interest in the cellular and humoral responses of shrimp, especially with respect to identification and characterization of immune effectors (Söderhäll \& Cerenius 1992, Bachere et al. 1995, 2000, Holmblad et al. 1999, Roch 1999, Arala-Chaves \& Sequeira 2000, Johanson et al. 2000, Vargas-Albores \& Yepiz-Plascencia 2000). It is expected that basic research on immune processes will lead to a better

${ }^{*}$ Corresponding author. E-mail: pamornra@ratree.psu.ac.th understanding of the immune response and provide for improved strategies of disease prevention, including genetic selection of disease-resistant animals from domesticated stocks.

Using modern techniques in molecular biology, work on shrimp immunology is progressing rapidly. Several genes involved in antimicrobial infection have been cloned and characterized. For example, antimicrobial peptides, penaeidins, have been cloned and expressed from Penaeus vannamei (Destoumieux et al. 1997, 1999); prophenoloxidase has been cloned from the black tiger prawn $P$. monodon (Sritunyalucksana et al. 1999); and the hemolymph-clotting protein has been cloned from P. monodon (Yeh et al. 1998, 1999). However, nothing has yet been reported regarding molecules involved in shrimp response to viruses.

In 1998, Flegel \& Pasharawipas presented a theory of viral accommodation which proposed that shrimp were capable of acquiring specific tolerance to viral pathogens by a process involving viral binding and 
memory. Venegas et al. (2000) subsequently reported a pseudo-immune phenomenon in Penaeus japonicus in which survivors of WSSV outbreak survived superinfection by WSSV and produced serum apparently capable of neutralizing WSSV preparations. Although the exact mechanism of specific viral tolerance proposed by the viral accommodation theory is unknown, it was proposed to be based on membrane binding and signal transduction pathways involving specific memory, leading to suppression of viral-triggered apoptosis and to persistent innocuous infections (Flegel \& Pasharawipas 1998, Flegel 2001).

We investigated specific mRNA products induced in shrimp in response to infection by WSSV. The recently described cDNA subtraction technology allows for identification of genes upregulated in response to various stimuli (Sin et al. 1998, Han et al. 1999, Fujiki et al. 2000, Stier et al. 2000, Zanders et at. 2000). This methodology was applied to our study for differential screening of cDNA libraries from normal and WSSVinfected shrimp.

\section{MATERIALS AND METHODS}

Shrimp. Adult Penaeus monodon $20 \mathrm{~g}$ in weight were obtained from a shrimp farm in Songkhla province, Thailand. They were kept individually in $60 \mathrm{l}$ aquaria for $2 \mathrm{~d}$ for acclimatization before experiments were started.

WSSV viral stock. WSSV stock for experimental infections was prepared according to the method described in Supamattaya et al. (1998). Gill tissue of WSSV-infected Penaeus monodon was dissected and homogenized in lobster hemolymph medium (LHM), pH 7.4 (Paterson \& Stewart 1974). The ratio of tissue to LHM was 1:10. After centrifugation at $3000 \times g$ for $10 \mathrm{~min}$ at $4{ }^{\circ} \mathrm{C}$, the supernatant was filtered through a $0.22 \mu \mathrm{m}$ sterile membrane. The stock solution of virus was kept in LHM buffer at $-80^{\circ} \mathrm{C}$ and thawed at $4^{\circ} \mathrm{C}$ before use.

WSSV experimental infections. For preparation of cDNA libraries, $200 \mu \mathrm{l}$ hemolymph was initially withdrawn from individual shrimp and labeled as normal hemolymph. It was stored at $-80^{\circ} \mathrm{C}$ until used. The shrimp were subsequently rested for $2 \mathrm{~d}$ while being fed with minced fresh fish. Then, individuals were injected with $10 \mu \mathrm{l}$ each of a $1: 10^{7} 0.85 \% \mathrm{NaCl}$ dilution of the viral stock solution and 100 to $150 \mu \mathrm{l}$ hemolymph was subsequently carefully withdrawn at $3,6,12$ and 24 h postinjection (p.i.) (10 shrimp each time). Hemolymph were pooled and stored at $-80^{\circ} \mathrm{C}$. The shrimp were raised for another $2 \mathrm{wk}$ in the aquaria and mortality was recorded.

For mRNA expression tests, 2 batches of shrimp were used to set up the experiment. In each batch, shrimp were divided into 1 control group of 25 and 1 test group of 25. Shrimp in the control group were injected individually with $10 \mu \mathrm{l}$ saline solution $(0.85 \%$ $\mathrm{NaCl}$ ) while those in the test group were injected with $10 \mu \mathrm{l}$ of a 1:106 dilution of the viral stock solution. After injection, hemolymph was withdrawn and pooled from 5 individuals of each group at $30 \mathrm{~min}, 1.5 \mathrm{~h}, 3 \mathrm{~h}, 6 \mathrm{~h}$ and $24 \mathrm{~h}$ for extraction of total RNA to be used in RT-PCR reactions.

Preparation of subtraction cDNA library. Total RNA was extracted from normal and infected hemolymph using Trizol reagent (GIBCO BRL). Purification of mRNA, synthesis of cDNA and subtraction of cDNA were carried out according to the manufacturer's instructions using a PCR-selected ${ }^{{ }^{\mathrm{M}} \mathrm{C}} \mathrm{CDNA}$ subtraction kit (CLONTECH Laboratories, Catalog no. K1804-1). The subtraction cDNA was prepared using cDNA from infected shrimp as the tester DNA (to be subtracted) and normal or cDNA from uninfected shrimp as the driver DNA (to subtract). The cDNA fragments amplified after subtractive hybridization were subcloned into pGEM-TEasy vector (Promega) and transformed into bacterial strain Top10F' (Invitrogen). The recombinant clones were then used as a library for screening.

Differential screening. To differentially screen the subtracted cDNA library, the method described in the PCR-selected CLONETECH ${ }^{\mathrm{TM}} \mathrm{CDNA}$ subtraction kit was modified. The subtracted library was hybridized with forward- and reverse-subtracted cDNA probes. The forward-subtracted probe was made from the same subtracted cDNA as used to construct the subtracted library. To make the reverse-subtracted probe, subtractive hybridization was performed with the infected cDNA as a driver and normal cDNA as the tester. The probes were labeled with Digoxigenin (DIG) as follows: in separate $0.5 \mathrm{ml}$ microcentrifuge tubes, $1 \mu \mathrm{g}$ (in $\mathrm{H}_{2} \mathrm{O} 15 \mu \mathrm{l}$ ) of each of forward- and reverse-subtracted cDNA was denatured in a boiling water bath for $10 \mathrm{~min}$ and quickly chilled on ice before $2 \mu \mathrm{l}$ hexanucleotide mixture, $2 \mu \mathrm{l} \mathrm{dNTP}$ and $1 \mu \mathrm{l}$ Klenow enzyme were added and mixed as recommended by the manufacturer (DIG DNA labeling kit, Boehringer Mannheim, Catalog no. 1175033). The hybridization was performed at $68^{\circ} \mathrm{C}$ overnight. Clones representing mRNAs that were truly differentially expressed hybridized only with the forward-subtracted probe. The clones were detected by colorimetric reaction with nitroblue tetrazolium and 5-bromo-4-chloro3-indolyl phosphate.

DNA sequencing and data analysis. DNA extracted from positive clones was sequenced using BigDye ${ }^{\mathrm{TM}}$ Terminator Cycle Sequencing Kits with AmpliTaq DNA polymerase (PE Applied Biosystems, Catalog no. P/N4303150) and an Applied Biosystems 377 sequencer (Perkin-Elmer). A search for related sequences using data from GenBank and SWISS-PROT was carried out. The amino acid sequences and their 
secondary structure were predicted using the computer program HIBIO DNASIS Version 2.

Reverse transcription polymerase chain reaction (RTPCR) analysis. To confirm the induction and differential expression of the detected sequences, RT-PCR analyses were performed. Primers (5'- and $3^{\prime}$-) were designed for each of the detected sequences and synthesized by Life Technologies. Oligonucleotides used as PCR primers were as follows: TE8 sense primer 5'-GAT TTG GCC GTC TCA CAA GTG CAG-3' and antisense primer 5'GCC TTA AGT TAC AGG TCG GGA ATG G-3'. Degenerate $\beta$-actin primers were designed according to the conserved amino acid sequences QLMFETF and MKCDVDI (Yeh et al. 1999) and used to amplify a PCR product of $500 \mathrm{bp}$ in the RT-PCR experiments as an internal control of gene expression. Total RNA (1 $\mu$ g each) from uninfected samples and infected samples were extracted by using the SV total isolation system (Promega, Catalog no. Z3100) for use as the template in $50 \mu \mathrm{l}$ of 1-step RT-PCR reaction mixture according to the manufacturer's instructions (QIAGEN OneStep RT-PCR, Catalog no. 210210, QIAGEN GmbH). The reaction started at $50^{\circ} \mathrm{C}$ for $30 \mathrm{~min}$ followed by an initial PCR activation step at $95^{\circ} \mathrm{C}$ for $15 \mathrm{~min}$ followed by 30 cycles of $94^{\circ} \mathrm{C}$ for $1 \mathrm{~min}, 48^{\circ} \mathrm{C}$ for $1 \mathrm{~min}$ and $72^{\circ} \mathrm{C}$ for $1 \mathrm{~min}$. The RT-PCR products were re-amplified for another 20 cycles and $5 \mu \mathrm{l}$ of each sample was electrophoresed on a 1.8\% agarose gel and visualized by ethidium bromide staining under ultraviolet (UV) light. The results from ethidium bromide-stained rRNA under UV-light was used as an indicator that similar amounts of total RNA were used in each RT-PCR. The identity of PCR products was confirmed by cloning into pGEM-TEasy (Promega) and by sequence analysis using the ABI prism 377 apparatus as described above.

Construction of full length DNA. To facilitate recovery of the total coding sequence of TE8 CDNA, rapid amplification of cDNA ends (RACE) was performed. Reagents for 5' and 3' RACE were purchased from Life Technologies and reactions were conducted according to instructions in the manual (GIBCO BRL, Catalog no. 18374-058). Gene-specific oligonucleotide primers were as follows: GSP-1: 5'-TTG TGT AAG GTA ACA GTT CTC C-3', GSP-2: 5'-CGA CTG TCT CTA ATG GCA AGG GAA-3', GSP-3: 5'-CGA GGA CTC TTC TTC AGC ATG TCA-3'.

\section{RESULTS}

\section{Shrimp morbidity and mortality}

None of the shrimp in the saline-injected group died or showed gross signs of disease throughout the $2 \mathrm{wk}$ period of the tests. In the WSSV injection group, 10 shrimp died within $1 \mathrm{wk}$ p.i. and showed gross signs of WSSV infection. The remaining 30 shrimp showed signs of weakness and lethargy for a few days but later recovered and survived to the end of the 2 wk test period.

\section{Differential cDNA library}

In an effort to identify virus-inducible genes in the hemolymph of Penaeus monodon, the mRNA of viral (WSSV)-infected shrimp (tester) and non-infected shrimp (driver) was isolated, reverse-transcribed into cDNA, digested with RsaI and cloned. Of 808 clones obtained in this library, 441 clones hybridized with both forward and reverse probes while 202 (positive clones) hybridized strongly with the forward-subtracted probe but not at all or only weakly with the reverse probe. Of the positive clones, 45 with insert fragment sizes ranging from 200 to $1000 \mathrm{bp}$ were selected for partial sequence analysis. The nucleotide sequences and deduced amino acid sequences for 3 frames were used to search the GenBank database. Amino acid sequences of 32 clones gave significant similarity to known genes in the data bank, while 13 clones showed no similarity to known genes. Among the 32 clones with significant similarity to known sequences, putative proteins of 3 clones (TE8, TE66 and 43S2) were reported in other works to be associated with signal transduction pathways. Of these, TE8 was chosen for more detailed study.

\section{Nucleotide and predicted amino acid sequence of TE8}

The TE8 cDNA clone obtained from the subtraction cDNA library consisted of 390 nucleotides. Using primers and the $5^{\prime}-, 3^{\prime}$-RACE technique (see 'Materials and methods'), the length of the cDNA was extended to $719 \mathrm{bp}$ and its nucleotide sequence was deposited at GenBank with the accession number AF335106. A deduced translated protein of 233 amino acids was predicted from the first reading frame with a TAA termination codon at nucleotide position 700. Sequence analysis using the BLAST (basic local alignment search tool) 2.0 algorithm showed that the TE8-deduced amino acid sequence had high similarity to human syntenin $(57 \%$ identity) and mouse syntenin (58\% identity). Two putative postsynaptic density protein (PDZ) domains of TE8 were identified by an 83 residue stretch of amino acids of PDZ1 (nucleotides 133 to 391) followed by a stretch of another 81 amino acids (nucleotides 392 to 630). The alignment of TE8-PDZ1 and TE8-PDZ2 with other known PDZ is shown in Fig. 1. Similar to syntenin-2 $\beta$ (Koroll et al. 2001), experiments on our 5'-RACE using 


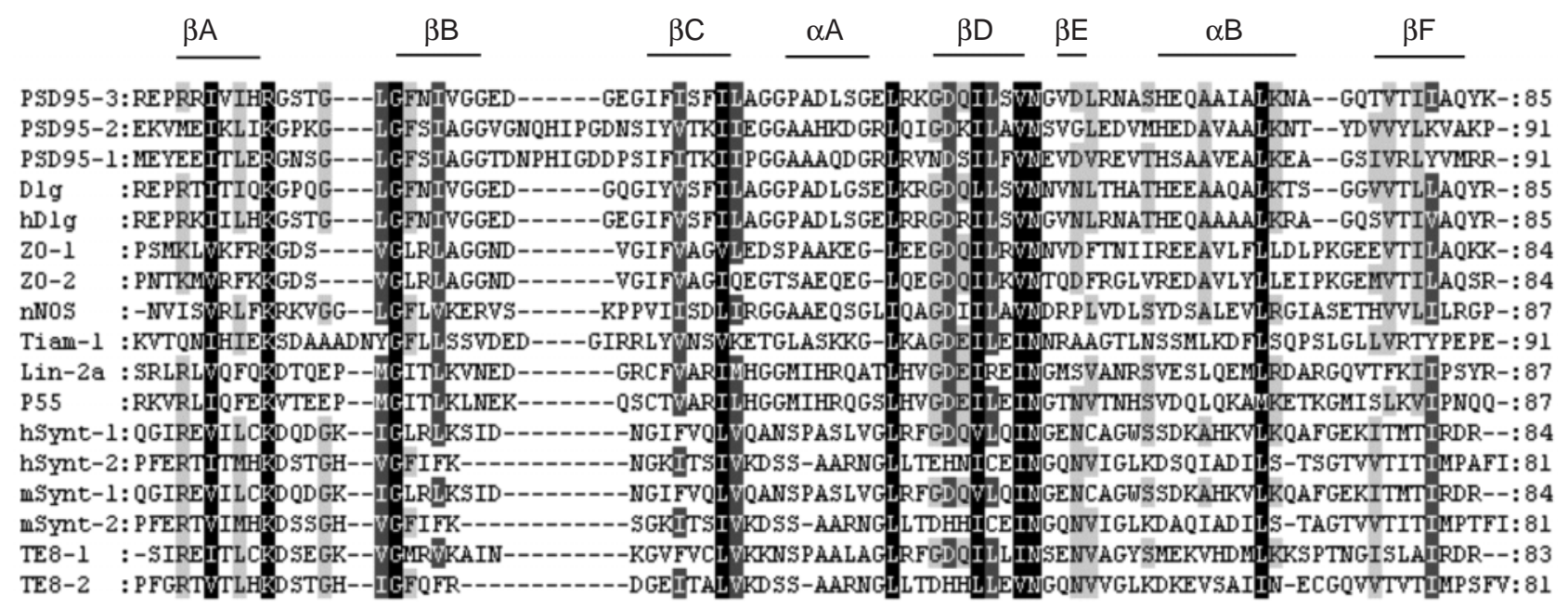

Fig. 1. Sequence alignment of the postsynaptic density protein (PDZ) domains with that of a syntenin-like protein (AF335106). The first PDZ (TE8-1) and second PDZ (TE8-2) domains of TE8 were aligned to the 3 PDZ domains of a rat brain postsynaptic density protein PSD-95 (M96853), PDZ-3 of the Drosophila discs-large (Dlg) protein (M73529), human homolog hDlg (U49089), PDZ2 of the human tight junction protein ZO-1 (L14837), PDZ-3 of human ZO-2 (L27152), the PDZ domain of rat neuronal nitric oxide synthase or nNOS (X59949), the PDZ domain of murine Tiam-1 (U05245), the PDZ domain of the Caenorhabditis celegans protein LIN-2a (X92564), the PDZ domain of human p55 erythrocyte membrane protein (M64925), the PDZ-1 (hSynt-1) and PDZ-2 (hSynt-2) domains of human syntenin (5032083), and the PDZ-1 (mSynt-1) and PDZ-2 (mSynt-2) domains of Mus musculus syntenin (AAC27646). The sequences were aligned by CLUSTAL X algorithm. The dashes represent gaps at the indicated proteins. Positions where the chemical character of residues is conserved in 100, 80 and $60 \%$ of sequences are highlighted in black, dark gray and light gray respectively

several primer pairs suggested that TE8 was probably a short isoform of a syntenin-like protein that lacked the N-terminal segment. Koroll et al. (2001) presented evidence that syntenin- $2 \beta$ was generated by an alternative splicing site and that it used the second methionine residue within the sequence of the longer isoform (syntenin-2 $\alpha$ ) as an alternative translational start site.

\section{Expression of specific mRNA in infected samples}

To investigate whether the gene-encoding TE8 protein was indeed inducible by viral infection, we performed RT-PCR analyses on total RNA extracts from saline-injected and WSSV-injected shrimp using specific primers designed from the TE8 sequences. RTPCR of the $\beta$-actin gene was used as internal control of gene expression to ensure that the RT-PCR for each sample contained the same amount of total RNA and that the RNA was intact. The purity of the isolated RNA was analyzed for DNA contamination by using RT-PCR in the presence (+RT) and absence (-RT) of reverse transcriptase (Fig. 2).

An increase in the amount of total RNA was observed shortly after injection in both the saline and viral injection groups. However, by RT-PCR, the TE8 transcript was detected only in the viral injection group. In Batch 1 shrimp, expression of TE8-specific mRNA was observed at $30 \mathrm{~min}$ and $1.5 \mathrm{~h}$ (p.i.) of WSSV

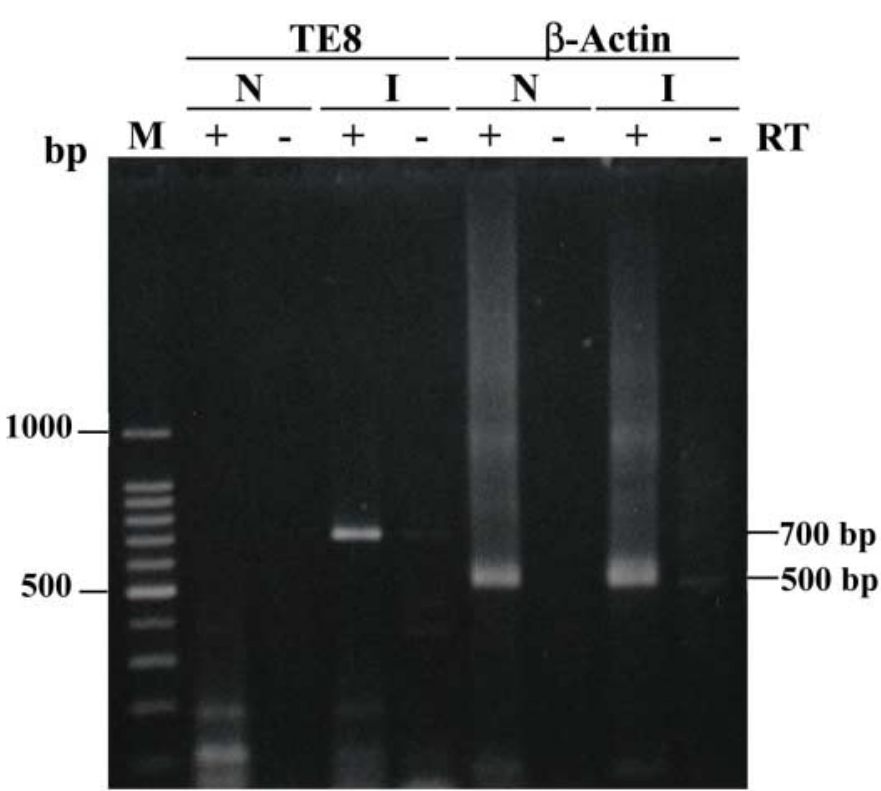

Fig. 2. Expression of TE8-specific mRNA in response to viral infection and expression of $\beta$-actin as an internal control. Total RNA was isolated from Penaeus monodon uninfected (N, saline injection) and infected with WSSV (I). RNA isolation, RT-PCR and the primer sequences were as described in 'Materials and methods'. The total RNA was analyzed for DNA contamination using RT-PCR in the presence $(+)$ and absence $(-)$ of reverse transcriptase. The molecular sizes of the resulting PCR products are shown in Lane 1 ( $\mathrm{M}=100 \mathrm{bp}$ ladder) 


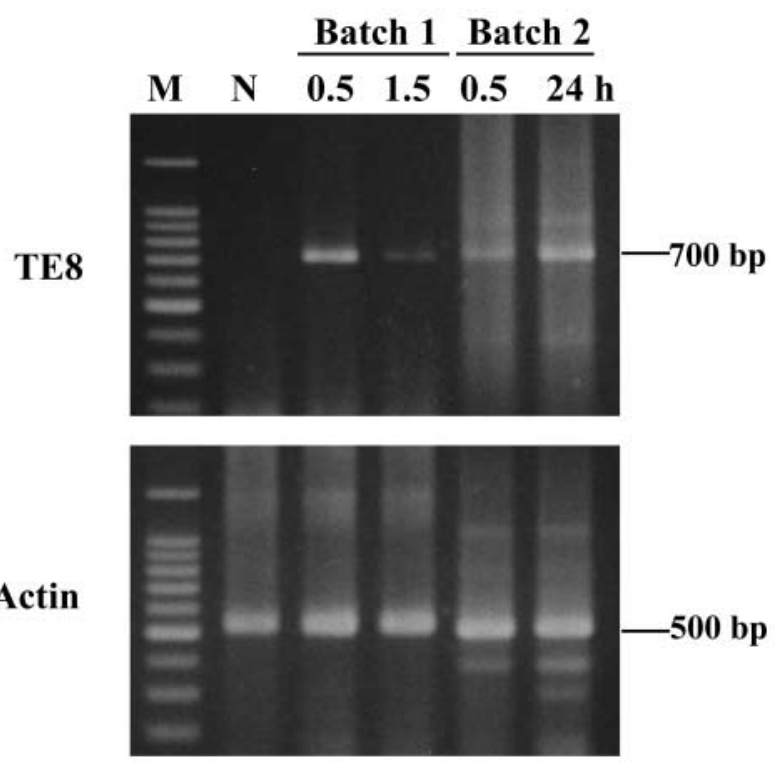

Fig. 3. Expression of TE8-specific mRNA at different times in comparison with expression of $\beta$-actin. Penaeus mondon was infected with WSSV and sampled at indicated times. Total RNA was isolated and RT-PCR was performed as described in 'Materials and methods'. The molecular sizes of the resulting PCR products are shown in Lane 1 ( $\mathrm{M}=100 \mathrm{bp}$ ladder). Lane $2(\mathrm{~N})$ is the product obtained from the RT-PCR reaction of saline-injected shrimp collected at $30 \mathrm{~min}(0.5 \mathrm{~h})$ postinjection. Lanes $3 \& 4$ are products obtained from RT-PCR reactions of WSSV-injected shrimp (Batch 1) collected at 0.5 and $1.5 \mathrm{~h}$ post-injection. Lanes $5 \& 6$ are products obtained from RT-PCR reactions of WSSV-injected shrimp (Batch 2) collected at 0.5 and $24 \mathrm{~h}$ post-injection

(Fig. 3). A faint band was seen at $3 \mathrm{~h}$ and no transcript was detected at $6 \mathrm{~h}$ (p.i.), indicating that the level of expression had dropped below detectable levels by that time (data not shown). In Batch 2 shrimp, RT-PCR revealed that TE8 was expressed at $30 \mathrm{~min}$ and remained high for at least $24 \mathrm{~h}$ (p.i.) (Fig. 3). The sizes of all the PCR products were as predicted from the sequences of their respective targets. No RT-PCR products were obtained from the total RNA samples derived from shrimp injected with saline. The RT-PCR products were excised from the gel, sequenced and confirmed to correspond to the sequence of TE8.

\section{DISCUSSION}

Native immune effectors are often difficult to identify because they are present in minute amounts and because they may be transient humoral reactions involved only in very early or immediate stages in the induction of superceding cascade defense processes (Smith \& Chisholm 1992, Söderhäll \& Cerenius 1992). We overcame these difficulties by applying PCR- coupled subtractive hybridization with cDNA from WSSV-infected and non-infected shrimp and identified TE8 as related to syntenin-like protein. Reports from studies of other organisms indicate that this protein is involved in signal transduction pathways. Confirmatory RT-PCR assays with TE8 mRNA showed that the expression was elevated from 30 min to $24 \mathrm{~h}$ (p.i.) of WSSV. The increase in amount of total RNA observed in both the saline and viral injection groups shortly after injection may have resulted from an increase in circulating hemocyte numbers in response to injection injury. However, control monitoring by RTPCR indicated that the TE8 transcript was elevated relative to the $\beta$-actin gene transcript. On the other hand, it was not possible for us to distinguish whether the TE8 transcript arose from pre-existing hemocytes or those newly emerging after WSSV injection. Whatever the source, however, it is reasonable to suggest that the TE8 transcript resulted from WSSV injection. At the same time, it is not possible to conclude that TE8 constitutes a specific response to WSSV or even viral infection in general. Further investigations using challenges with bacteria, other pathogens or even various stress factors would be necessary to establish this. For example, syntenin-like proteins are known to mediate production of gene products (details in the next paragraph) important in wound healing and innate immunity (review by Bernfield et al. 1999).

The fact that the TE8 transcript gave higher homology to human syntenin than Drosophila syntenin might suggest to some readers that our TE8 transcript arose from contamination by human nucleic acid. However, this can be discounted for 2 reasons. First, the sequence is not identical to that of human syntenin. Second, we performed a Southern blot hybridization test (data not shown) that clearly showed TE8 DNA hybridized with EcoRI-digested Penaeus monodon chromosomal DNA but not to the human DNA.

This report is the first suggesting that a syntenin-like protein could be involved in the response to a viral pathogen. Syntenin was originally identified as an adapter protein binding to the cytoplasmic domain of syndecans, which plays a major role in cell-cell and cell-matrix interactions (Grootjans et al. 1997). The interaction of syndecans with syntenin is mediated by its 2 PDZ domains. PDZ domains are motifs of about 80 to 90 amino acids. They were originally identified as repeated regions of homology between the product of the synaptic protein PSD-95 and the Drosophila dlg tumor suppressor gene (Dlg-A) (Cho et al. 1992, Kornau et al. 1995). The name PDZ domain is derived from the names of 3 proteins containing such domains, PSD95, Dlg-A and ZO-1 (Ponting \& Phillips 1995). PDZ domains have now been identified in over 50 different proteins, which for the most part appear unrelated to 
one another. Although PDZ domain-containing proteins are able to interact with different proteins (Saras et al. 1996), almost all those known are associated with the cell membrane. Thus, these domains may be involved in either organizing transmembrane proteins at the plasma membrane or in recruiting proteins from the cytosol (Fanning \& Anderson 1996).

Based on the crystal structures of PSD-95 and Dlg-A, PDZ domains are composed of 5 or $6 \beta$-strands ( $\beta / A$ $\beta / \mathrm{F}$ ) and $2 \alpha$-helices ( $\alpha / \mathrm{A}$ and $\alpha / \mathrm{B}$ ) (Morais et al. 1996). Peptide binding can be envisioned as the addition of another $\beta$-strand to the $\beta$-sheet of the PDZ domain (Harrison 1996). In the analysis of our protein, a computer-assisted comparison of the predicted amino acid sequence and the secondary structure revealed $6 \beta$ strands and $2 \alpha$-helices in the predicted TE8 protein. The domains belong to the same group of syntenins a, p55 and LIN-2a since they lack a basic residue at the first amino acid of $\alpha / \mathrm{B}$ ( $\mathrm{M}$ in the TE8-1, D in the TE8-2) (Fig. 3). This residue was reported to play an important role in the binding specificity to the C-terminal FYA sequence of syndecans (Grootjans et al. 1997).

By analogy, syntenin-like TE8 has the potential to act in a similar fashion to syntenin. Since syntenin has no obvious catalytic domain and is therefore unlikely to be involved directly in signaling, it could serve as an adapter or scaffold protein to attach syndecans to signaling components. The syndecans too, have no known intrinsic signaling activity, but interact with tyrosine kinase receptors (Henkemeyer et al. 1996, Holland et al. 1996, Steinfeld et al. 1996, Bruckner et al. 1997, George et al. 1998) to form multimeric protein complexes that mediate receptor clustering or coupling of proteins to downstream signal components (Mellitzer et al. 2000).

How TE8 might be involved in the shrimp response to WSSV infection is open to speculation. Further work is required to screen for known or novel polypeptides that might interact with TE8. Characterization of the binding process, identification of downstream components and investigation as to whether the tyrosine kinase is involved similarly to other PDZ containing proteins (Lin et al. 1999) would be good places to start. These studies, along with the further investigation of other differentially expressed cDNAs will help to determine the relevance of each component and the role of signal-transduction pathways in the shrimp response to viral pathogens.

Acknowledgements. P.G. was supported by the Graduate School, Prince of Songkla University to Potchanapond Graidist, and P.B. by the Royal Golden Jubilee Graduated Program from Thailand Research Fund. We thank Prof. Dr. Timothy Flegel for a critical reading of the manuscript and discussion. We are grateful to Prof. Dr. Borre Robertson for valuable comments.

\section{LITERATURE CITED}

Arala-Chaves M, Sequeira T (2000) Is there any kind of adaptive immunity in invertebrates. Aquaculture 191:247-258

Bachere E, Mialhe E, Noel D, Boulo V, Morvan A, Rodriguez J (1995) Knowledge and research prospects in marine mollusc and crustacean immunology. Aquaculture 132: $17-32$

Bachere E, Mialhe E, Rodriguez J (1995) Identification of defense effectors in the haemolymph of crustaceans with particular reference to the shrimp Penaeus japonicus (bate) prospects and applications. Fish Shellfish Immunol 5:597-612

Bachere E (2000) Shrimp immunity and disease control. Aquaculture 191:3-11

Bernfield M, Gotte M, Park PW, Reizes O, Fitzgerald ML, Lincecum J, Zako M (1999) Functions of cell surface heparan sulfate proteoglycans. Annu Rev Biochem 68: 729-777

Bruckner K, Pasquale EB, Klien R (1997) Tyrosine phophorylation of transmembrane ligands for Eph receptors. Science 275:1640-1643

Cho, KO, Hunt, CA, Kennedy, MB (1992) The rat brain postsynaptic density fraction contains a homolog of the Drosophila discs-large tumor suppressor protein. Neuron 9: 929-942

Destoumieux D, Bulet P, Loew D, van Dorsselaer A, Rodriguez J, Bachere E (1997) Penaeidins: a new family of antimicrobial peptides isolated from the Penaeus vannamei (decapoda). J Biol Chem 272:28398-28406

Destoumieux D, Bulet P, Strub JM, van Dorsselaer A, Bachere E (1999) Recombinant expression and range of activity of penaeidins, antimicrobial peptides from penaeid shrimp. Eur J Biochem 266:335-346

Fanning AS, Anderson JM (1996) Protein-protein interactions: PDZ domain networks. Curr Biol 6:1385-1388

Flegel TW (1997) Special topic review: major viral diseases of the black tiger prawn (Penaeus monodon) in Thailand. World J Microbiol Biotech 13:433-442

Flegel TW (2001) The shrimp response to viral pathogens. In: Browdy CR, Jordy DE (eds) The new wave: proceedings of the special session on shrimp, World Aquaculture 2001, Orlando. World Aquaculture Society, Boca Raton, FL, p 190-214

Flegel TW, Pasharawipas T (1998) Active viral accommodation: a new concept for crustacean response to viral pathogen. In: Flegel TW (ed) Advances in shrimp biotechnology. National Center for Genetic Engineering and Biotechnology, Bangkok, p 245-250

Fujiki K, Shin D, Nakao M, Yano T (2000) Molecular cloning and expression analysis of carp (Crypprinus carpio) interleukin-1 $\beta$, high affinity immunoglobulin E FC receptor $\gamma$ subunit and serum amyloid A. Fish Shellfish Immunol 10: $229-242$

George SE, Simokat K, Hardin J, Chisolm AD (1998) The VAB-1 Eph receptors tyrosine kinase functions in neural and endothelial morphogenesis in C. elegans. Cell 92: 633-643

Grootjans JJ, Zimmermann P, Reekmans G, Smets A, Degeest G, Durr J, David G (1997) Syntenin, a PDZ protein that binds syndecan cytoplasmic domains. Proc Nat Acad Sci USA 94:13683-13688

Han YS, Chun J, Schwartz A, Nelson S, Paskewitz SM (1999) Induction of mosquito hemolymph proteins in response to immune challenge and wounding. Dev Comp Immunol 23: $553-562$

Harrison SC (1996) Peptide-surface association: the case of 
PDZ and PTB domains. Cell 86: 341-343

Henkemeyer M, Orioli D, Henderson JT, Saxton TM, Roder J, Pawson T, Klein R (1996) Nuk controls pathfinding of commissural axons in the mammalian central nervous system. Cell 86:35-46

Holland SJ, Gale NW, Mbamalu G, Yancopouloe GD, Henkemeyer M, Pawson T (1996) Bidirectional signalling through the Eph-family receptor Nuk and its transmembrane ligands. Nature (Lond) 383:722-725

Holmblad T, Söderhäll K (1999) Cell adhesion molecules and antioxidative enzymes in a crustacean, possible role in immunity. Aquaculture 172:111-123

Johanson MW, Keyser P, Sritunyyalucksana K, Söderhäll K (2000) Crustacean haemocytes and haematopoeisis. Aquaculture 191:45-52

Kornau, HC, Schenker, LJ, Kennedy, MB, Seeburg, PH. (1995) Domain interaction between NMDA receptor subunits and the postsynaptic density protein PSD-95. Science 296:1737-1740

Koroll M, Rathjen FG, Vilkmer H (2001) The neural cell recognition molecules neurofascin interacts with syntenin-1 but not with syntenin-2, both of which reveal selfassociating activity. J Biol Chem 276:10646-10654

Lin D, Gish GD, Sonyang Z, Pawson T (1999) The carboxyl terminus of B class ephin constitutes a PDZ domain binding motif. J Biol Chem 274:3726-3733

Mellitzer G, Xu Q, Wilkinson DG (2000) Control of cell behavior by signalling through Eph receptors and ephins. Curr Opin Neurobiol 10:400-408

Morais Cabral JH, Petosa C, Sutcliffe MJ, Raza S and 5 others (1996) Crystal structure of a PDZ domain. Nature (Lond) 382:649-652

Paterson WD, Stewart JE (1974) In vitro phagocytosis by hemocytes of American lobster (Homarus americanus). J Fish Res Board Can 31:1051-1056

Ponting, CP, Phillips, C (1995) DHR domains in syntrophins, neuronal NO synthases and other intracellular proteins. Trends Biol Sci 20:102-103

Roch P (1999) Defense mechanisms and disease prevention in farmed marine invertebrates. Aquaculture 172:125-145

Saras J, Heldin CH (1996) PDZ domains bind carboxyterminal sequences of target proteins. Trends Biochem Sci 21:455-458

Sin SW, Park S, Park D, Kim MG, Kim SC, Brey PT, Park H

Editorial responsibility: Timothy Flegel,

Bangkok, Thailand
(1998) Isolation and characterization of immune-related genes from the wall webworm, Hyphantria cunea, using PCR-based differentiation display and subtractive cloning Insect Biochem Mol Biol 28:827-837

Smith VJ, Chisholm JRS (1992) Non-cellular immunity in crustaceans. Fish Shellfish Immunol 2:1-3

Söderhäll K, Cerenius L (1992) Crustacean immunity. Annu Rev Fish Dis 2:3-23

Sritunyalucksana K, Cerenius L, Soderhall K (1999) Molecular cloning and characterizatuion of prophenoloxidase in the black tiger shrimp, Penaeus monodon. Dev Comp Immunol 23:179-186

Steinfeld R, van den Berghe H, David G (1996) Stimulation of fibroblast growth factor receptor-1 occupancy and signalling by cell surface-associated syndecans and glypican. J Cell Biol 133:405-416

Stier S, Totzke G, Grunewald E, Neuhaus T and 5 others (2000) Identification of syntenin and other TNF-inducible genes in human umbilical arterial endothelial cells by suppression subtractive hybridization. FEBS Lett 467:299-304

Supamattaya K, Hoffmann RW, Boonyaratpalin S, Kanchanaphum P (1998) Experimental transmission of white spot syndrome virus (WSSV) from black tiger shrimp Penaeus monodon to the sand crab Portunus pelagicus, mud crab Scylla serrata and krill Acetes sp. Dis Aquat Org 32:79-85

Vargus-Albores F, Yepiz-Plascencia G (2000) Beta glucan binding protein and its role in shrimp immune response. Aquaculture 191:13-21

Venegas CA, Nonaka L, Mushiake K, Shimizu K, Nishizawa T, Muroga K (1999) Pathogenecity of penaeid rod-shaped DNA virus (PRDV) to kuruma prawn in different developmental stages. Fish Pathol 34:19-23

Yeh MS, Chen YL, Tsai IH (1998) The hemolymph clottable protein from tiger shrimp, Penaeus monodon, and related species. Comp Biochem Physiol B 121:169-176

Yeh MS, Huang CJ, Leu JH, Lee YC, Tsai IH (1999) Molecular cloning and characterization of a hemolymph clottable protein from tiger shrimp (Penaeus monodon). Eur J Biochem 266:624-633

Zanders ED, Goulden MG, Kennedy TC, Kempsell KE (2000) Analysis of immune system gene expression in small rheumatoid arthritis biopsies using a combination of subtractive hybridization and high-density cDNA arrays. J Immunol Meth 233:131-141

Submitted: February 9, 2001; Accepted: September 4, 2001 Proofs received from author(s): March 27, 2002 